\title{
Frida Kahlo's Self-Identity: An Analysis of Self-Portrait on the Borderline Between Mexico and the United States
}

\author{
Leyuan $\mathrm{Ma}^{1}$ \\ ${ }^{1}$ The Experimental High School Attached to Beijing Normal University, China \\ Correspondence: Leyuan Ma, The Experimental High School Attached to Beijing Normal University, China.
}

Received: August 3, 2020

doi:10.11114/ijsss.v8i6.5025

\author{
Accepted: August 31, $2020 \quad$ Available online: September 24, 2020 \\ URL: https://doi.org/10.11114/ijsss.v8i6.5025
}

\begin{abstract}
Self-Portrait on the Borderline Between Mexico and the United States by the Mexican artist Frida Kahlo reveals a multitude of insights. This paper assesses how the nuances embodied in the painting serve as critical clues to comprehend Frida Kahlo's personal experiences, Mexican culture, and the approach of discovering the contextual background through the work of art. Beginning with a detailed formal analysis of the portrait, this paper further explores it by making connections with contextual evidence. Through timely reference to Frida Kahlo's political stance, cultural identity, and health, the paper demonstrates how the painting proffers insight into both the artist's life and Aztec culture.
\end{abstract}

Keywords: Frida Kahlo, Self-Portrait on the Borderline Between Mexico and the United States, self-portrait, art history, Aztec culture

\section{Introduction}

A renowned Mexican artist commonly associated with Surrealism or Magical Realism, Frida Kahlo implicitly addresses and explores discourses in Mexican society such as identity, postcolonialism, and gender, as well as her own personal experience and emotions. This paper explores her work, Self-Portrait on the Borderline between Mexico and the United States (fig.1),painted in 1932 when she was living in Detroit with her husband, Diego Rivera. The painting, besides capturing Kahlo's iconic features, reflects some of her deepest concerns during that time pertaining to her political stance, cultural identity, and well-being, specifically her pregnancy. Furthermore, by epitomizing Aztec imageries and her personal experiences, Frida also conveys her understanding of the cycle of death and rebirth.

\section{Formal Analysis}

Oriented horizontally, the painting features a full-length portrait of Frida Kahlo. Roughly in the middle of the canvas, Frida stands on a boundary stone that demarcates the US-Mexico border, akin to a statue atop a pedestal. Inscribed "Carmen Rivera painted her portrait in 1932," the stone features a combination of Frida's Christian name and her husband's last name. Frida is donned in the garb of a socialite debutante: a bright pink frock, lace gloves, and red slippers. However, as Carol E. Miller (1996) states in a poem about the painting, "nipples glare through her dress." Frida's femininity and liberality are underscored by the stark contrast between her fancy clothing and Miller's judgmental observation. With her face in three-quarter view, Frida stares straight out at the viewer with an intense expression; her gaze is steady under her iconic unibrow, her mouth pursed as if in deep thought. In her left hand she holds a Mexican flag and in her right, a cigarette.

Evenly balanced, the composition is almost equally bifurcated by Frida's body. To Kahlo's left is the natural landscape of Mexico, teeming with plants and Aztec relics, while to her right, the factories, skyscrapers, and machines represent modern America. On the American side, four factory chimneys with the word "FORD" on their sides emit smoke in front of a mass of skyscrapers. Four peculiar machines are placed in front of the buildings, their metal ducts extending to the foreground and ending in a row of electric appliances. On the Mexican side, the environment is less advanced. In the upper-left corner, a sun and a moon hover abreast above a half-ruined. In front of the temple is a pile of rubble, beside which lies a stone skull. The foreground shows the content beneath the surface of the ground: a row of plants flourishes in the lower-left corner, their roots connected to the cords of the electronics on the American side. Two Aztec sculptures depicting human figures stand between the debrisand the flora. 
Compared with Frida's dress, the background colors are relatively low in saturation and feature an earthy tone that spotlights her bright figure as the focal point of the composition. Frida's brushwork is smooth and meticulous, deluging the portrait with details. Devoid of a distinct light source, the painting features an unpronounced sense of volume due to the low contrast between light and shadows. The sole sense of depth originates from the overlapping of objects. All in all, the flatness of the painting and the strangeness of its elements combine to give it an unrealistic sense, as if it were a scene from a dream.

Finally, the materials used for the self-portrait are also quite interesting. Kahlo employed oil paints on tin for the painting, in the genre of a retablo, a religious form of art. In Mexico, retablosare small oil paintings typically completed on sheets of tin that portray holy personages in Christianity. Thought to contain miraculous powers, retablos were created by devout believers instead of trained artists (Castro-Sethness, 2004).

\section{Analysis and Interpretation in Context}

To better comprehend Frida's self-portrait, we must move beyond visual aspects to evaluate the contextual determinants of Frida's own experiences. During her lifetime, Frida was constantly involved in the politics of her country. A tireless protector of Mexico's independence, she even insisted on attending a public protest of American imperialism only a few days before her death. Her ideal of an independent Mexico coincided with her interest in her cultural roots, and both her political and cultural identities can be seen in her artworks.

In the early 1920's, Frida Kahlo's interest in politics compelled her to join the Mexican Communist Party (Helland, 1990). Stalin's nationalism appealed to her wish of a united, independent Mexico. In the early $20^{\text {th }}$ century, the U.S. started to interfere in Mexico's internal political struggles between capital and labor.Consequently, her political rhetoric became decidedly anti-American,as epitomized by her letter to Dr. Leo Eloesser, Coyoacan in 1931:

"Mexico is, as always, disorganized and messed up. The only thing it has left is the great beauty of the land and of the Indians. Every day, the ugly part of the United States steals a piece; it is a shame, but people have to eat, and it is inevitable that the big fish eat the small one...." (Zamora, 2006)

In the letter, Frida expresses her attitudes towards Mexico and the United States. Concerned for her own country as it struggles to attain an independent cultural identity, she clearly holds a negative view of the United States, the robber of Mexico's beauty.

These feelings are apparent in Self-Portrait on the Borderline Between Mexico and the United States (fig.1). For example, consider the national flags presented in the painting. In the sky, the American flag is enclosed in smoke from factories, suggesting Frida's criticism of America's industrialization. Kahlo holds a Mexican flag in her left hand and points it towards her home country. Though she is on the borderline between the two nations, her heart is clearly with Mexico. Moreover, the temple in the background is half-destroyed, and a faultline runs across the ground in front of it, possibly hinting at the slow disintegration ofthe "great beauty of the land and of the Indians", an explicit concern for the survival ofMexico's indigenous culture in the modern, turbulent world. Finally, the roots of the Mexican plants are connected to the electric cords of the American machines, symbolizing the connection between the two countries. Methodically creeping over to the more backwards Mexico, America's modernity and superior power gnaw away at Mexican cultural roots.

Frida Kahlo's nationalistic ideals naturally led to a deep interest in indigenous Mexican culture. Since she admired the Aztecs' unification of a large area of the Middle Americas, she developed a proclivity for Aztec culture which coincided with her aspiration for a consolidated, independent Mexico. Frida was also a fervent advocate of Mexicanidad, a romantic nationalism that, via traditional art and artifacts, united all indigenistas regardless of their political stances (Helland, 1990). After the Mexican Revolution (1910-1920), the nationalists sought the glorification of ancient and pre-colonial Mexico, especially Aztec imagery, as a source of purity and honor in the construction of a post-Revolutionary conscience (Castro-Sethness, 2004). Influenced by these thoughts, Kahlo profoundly revered Aztec imagery and incorporated it into her work.

In the painting, the left part of the middle ground contains several Aztec artifacts-a stone skull and figurines, all indigenous Mexican culturalelements, and the temple in the upper-left corner which resembles the Main Temple Area at Tenochtitlan in one of Fray Bernadino de Sahugun's $16^{\text {th }}$-century codices or the drawing of Montezuma's Palace in the Codex Mendoza (Helland, 1990). In yet another example of Frida Kahlo's affinity for traditional Mexican art, the entire painting is rendered in a primitive or naïve folkloric style, similar to that found on retablos, and the medium of the work - oil on tin - is also representativeof retablo.

Albeit a plethora of scholars have discussed the connections between the painting and Frida's own political stance and cultural heritage, few of them have looked into their relation with Kahlo's physical state. The paucity of investigation into her pertinent life events such as her pregnancy or the lifelong injuries she suffered from an accident when she was 
18 have inspired me to propose a new perspective on the portrait - that Frida Kahlo's work might also reflect her fears, anxieties, and hopes during her second pregnancy in 1932.

In 1925, Frida was involved in a terrible streetcar accident. Impaled by a handrail, she suffered great damage, inclusive of spinal and pelvic fractures. These medical conditions plagued Frida throughout her life and obstructed her pregnancies. During her convalescence, Frida sought refuge in her childhood hobby of drawing, thus beginning her artistic career. In 1927, Frida met the famous Mexican muralist Diego Rivera and married him the following year. Together, in the late 1920's and the early 1930's, they travelled around Mexico and the United States together. In April 1932, Frida moved to Detroit with her husband. There, she created this self-portrait (Reis, 2016).

Also in the spring of 1932 Frida became pregnant. She was extremely concerned about her health, as she had already lost a child in 1929 due to the injuries she suffered in the accident in 1925 (Zetterman, 2006). Her anxiety can also be evidenced from a letter she authored to Dr. Leo Eloesser on May 26, 1932:

"Two years ago, I had a surgical abortion in Mexico, more or less under the same circumstances as now, after a pregnancy of three months. This time it's been only two [months], and I think it would be easier, but I don't know why Dr. Pratt thinks it would be better to have the child...... but if you really share Dr. Pratt's opinion that it would be much better for my health not to have an abortion and to have the child, all those difficulties can be solved in one way or another.... In case the abortion was more advisable, I beg you to write Dr. Pratt...An insignificant mistake, and I could be taken away by la pelona(death)." (Zamora, 1995)

In the letter, Frida's ambivalence towards her pregnancy is evident. Previously, she had failed to abort the child. Now, her doctor urged her to continue the pregnancy, but Frida feared that her poor health would lead to her demise while giving birth. Her worries were well-founded, as she experienced a near-fatal miscarriage in July1932, not long after the letter. During this tumultuous period, she painted the self-portrait on the border; one could speculate that the portrait might contain symbols indicative of Frida's worries about her health and pregnancy.

In the foreground of the painting, a row of flowering plants highlights the fecundity and vitality of indigenous Mexico, an unequivocal contrast with the industrialized, yet moribund America; the flora might also convey Frida's yen for a "bountiful" or successful pregnancy. In addition, Frida chose to dress in the typical female attire, without a brassiere. Whilst scholars believe that this choice of clothing provides a powerful critique of the systems of oppression that marginalize indigenous women, Frida could have conceivably feminized herself as a reflection of the stereotypical role of women - to bear and raise children (Reis, 2016).

Additionally, a closer inspection of the artifacts on the ground to Frida's left proves fruitful. Consider the stone skull lying on its side in the background. In Mexican culture, skulls are potent emblems of death, due to the heightened focus on the deceased. During her pregnancy when she repeatedly contemplated the possibility of her demise, Frida may have projected her fears via the skull. Moreover, in yet another allusion to death (Helland, 1990), the squatting figure in front of the skull is a pastiche of the many squatting figures prevalentin Aztec sculpture, such as the kneeling death goddesses who wear skulls or hand trophy necklaces (c. 1300 A.D.: Museo Nacional de Antropologia, Mexico City).

Analysis of Aztec mythology might also yield some interesting interpretations. Commonly identified as the Main Temple Area at Tenochtitlan (Helland, 1990) and referred to as the Templo Mayor, the half-ruined temple of the composition's upper-left corner was partially a symbolic representation of the Hill of Coatepec, where according to Mexican myth, Huitzilopochtli, the god of the sun and war, was born. His mother, the goddess Coatlique, was magically impregnated by a ball of feathers and subsequently gave birth to him, the moon, and the stars.Despite the lack of iron clad connections, some subtle hints do disclose Frida's concerns about her health and pregnancy at the time in which she created the self-portrait.

Finally, I am extrapolating that Frida's artwork might also have been influenced by the traditional Mexican concept of life and death. After her terrible, almost fatal streetcar accident, then, in 1932, she was facing that terrible prospect again. When one amalgamates Frida's near-tragic encounters with her zealous support of Aztec culture, the relationship between ancient Aztec beliefs and Frida's self-portrait becomes evident.

The Aztecs believed that death could be followed by rebirth, and fate was determined by the manner whereby one perished. For instance, women who died in childbirth were believed to accompany the sun from noon to sunset in the afterlife. Other people were destined for Mictlan, a vehicle to receive the dead. The earth, which was the womb in which corn seeds were planted, was also where the dead remained in Mictlan to be born (De Orellana et al., 2009). For Aztecs, via intricate converses, death represented a disparate state that was integrated into their world view (De Orellana et al., 2009). Frida embodied this idea in her portrait: above the Templo Mayor, the sun and the moon coexist in the sky; life and death take turns exerting authority. Every evening, just as life is snatched by death, the moon drives away the sun with the darkness it befalls; however, at daybreak, just as rebirth occurs, the sun's rays overwhelm those 
of the moon. In addition, the sun and moon in Frida's painting are linked by clouds and lightning, a possible reference to the Aztec philosophy of rebirth via the unification of life and death

Incorporation of Frida's political-cultural identity and her own personal health conditions is not limited to her self-portrait. For instance, in one of her final paintings, Marxism Will Give Health to the Sick (fig.2), the artist depicts her utopian ideals. Socialism, symbolized by the face of Karl Marx, can rehabilitate her and bring peace to the whole world. As with the contrast between industrial America and pre-Columbian Mexico in Self-Portrait on the Borderline Between Mexico and the United States (fig.1), the hand that strangles the American eagle exemplifies Kahlo's contempt towards American capitalism and imperialism. Moreover, Frida Kahlo reveals her fascination with her indigenous culture by appearing in a traditional Mexican dress set in a backdrop of violent, murderous elements characteristic of Mexican folk art. Finally, she sketches herself throwing away her crutches while the hands of Socialism reach around her orthopedic corset to free her of her sufferings; this imagery represents a desirethat originates from her ailing health, just as the self-portrait on the border reflects her consternations and longings due to her pregnancy and poor physical health. Even at the end of her life, Frida's mind was occupied by her political ideas and cultural heritage, and her body was plagued by the injuries suffered at the tender age of 18 .

\section{Conclusion}

Self-Portrait on the Borderline Between Mexico and the United States (fig.1) is not merely a portrait of the artist. Instead, the painting also underscores some fundamental concerns that constantly appear in Frida's artworks through the exploration of her Aztec roots. The allusions to Frida's political ideals and cultural beliefs are conspicuous, and considering her personal experience, it is reasonable to suggest that Kahlo's concerns about her second pregnancy also influenced the painting. Her strenuous experience of pregnancy echoes the ambiguous, fluid "Borderline" between death and rebirth in Aztec mythology, giving deeper meaning to this work. Though many portraits might only be surface images of people, Frida supersedes them by leveraging her art to successfully demonstrate her own self-identity and inner world.

\section{References}

Castro-Sethness, M. (2004). Frida Kahlo's Spiritual World: The Influence of Mexican Retablo and Ex-voto Paintings on Her Art. Woman's Art Journal, 25(2), 21-24.

De Orellana, M., Pope, Q., Moctezuma, E., Nagao, D., Balderas, X., Cué, L., ... Adès, T. (2009). THE AZTECS-MEXICA AND DEATH: A Rebirth of Gods and Men. Artes De México, 96, 65-80. Retrieved July 30, 2020, from www.jstor.org/stable/24317808

Helland, J. (1990). Aztec Imagery in Frida Kahlo's Paintings: Indigenity and Political Commitment. Woman's Art Journal, 11(2), 8-13. Retrieved July 30, 2020, from www.jstor.org/stable/3690692

Miller, C. (1996). Self-Portrait on the Border Line between Mexico and the United States, Frida Kahlo, 1932. Frontiers, $17(3)$.

Reis, S. (2016). Frida Kahlo: The Complexity of Being. Essay Contest, 2017(2). Retrieved July 30, 2020, from https://ir.lib.uwo.ca/essay-contest-2017/2

Zamora, M. comp. (1995). Excerpts from the Letters of Frida Kahlo: Cartas Apasionadas. San Francisco, CA: Chronicle Books.

Zetterman, E. (2006). Frida Kahlo's Abortions: With Reflections from a Gender Perspective on Sexual Education in Mexico. Konsthistorisk Tidskrift, 75(6), 230-243. 


\section{Illustration List}

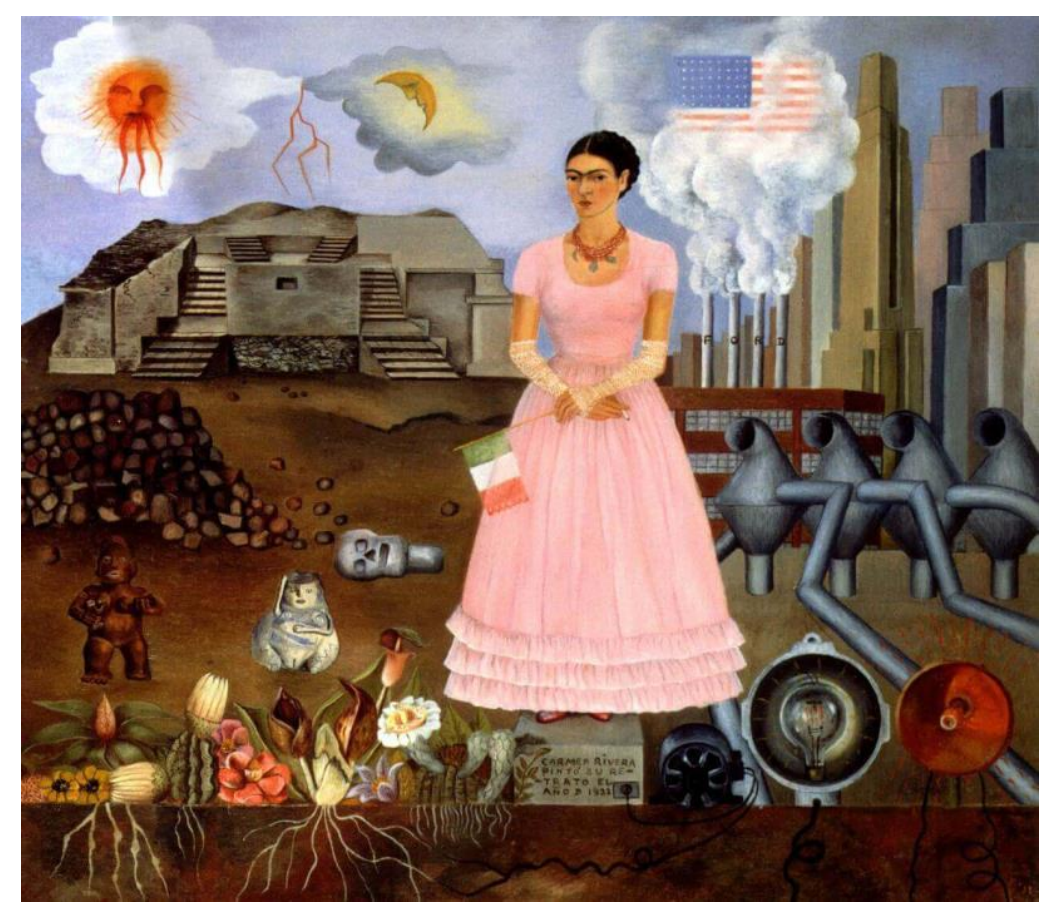

Figure 1. Frida Kahlo, Self-Portrait on the Borderline between Mexico and the United States, 1932, oil on metal

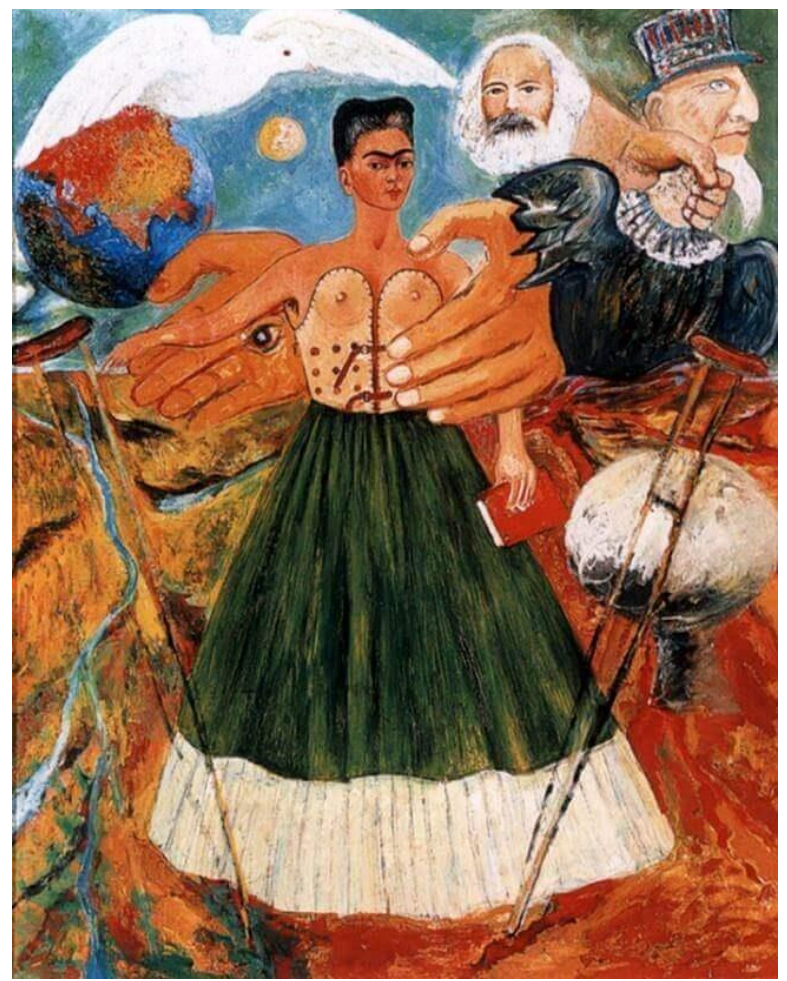

Figure 2. Frida Kahlo, Marxism Will Give Health to the Sick, 1954, oil on masonite

\section{Copyrights}

Copyright for this article is retained by the author(s), with first publication rights granted to the journal.

This is an open-access article distributed under the terms and conditions of the Creative Commons Attribution licensewhich permits unrestricted use, distribution, and reproduction in any medium, provided the original work is properly cited. 